\title{
Disclosure of whistle blowing policy among Malaysian listed companies
}

\begin{abstract}
This paper reports on the adoption of whistle blowing policies among Malaysian listed companies following the introduction of the Whistle Blower Protection Act 2010 and the formal recognition of having a whistle blowing policy as part of good corporate governance practice as contained in the revised Code of Corporate Governance, 2012. Based on a matched pair of 22 PN 17 companies and 22 non- PN 17 companies the study finds that only $53 \%$ of sampled firms in both categories disclosed they have a whistle blowing policy. The policies were examined using the lens of organizational justice framework. Disclosures indicate a formal whistle blowing policy was put in place in direct response to The Whistle Blower Protection Act 2010 and elements of procedural, distributive and interactional justice were evident in the items disclosed suggesting the institutionalization of an effective whistleblowing policy.
\end{abstract}

Keyword: Code of Corporate Governance 2012; Organisational Justice and Whistle Blower Protection Act 2010; PN 17 companies; Whistle blowing policies 